\title{
Polymeric Membrane for Verteporfirin Purification
}

\begin{abstract}
STEFANIA SIMIONESCU ${ }^{1,2}$, SOFIA TEODORESCU ${ }^{5}$, RODICA MARIANA ION ${ }^{3,4 *}$, ELENA VOICILA ${ }^{1}$, GHEORGHE NECHIFOR $^{1}$
'Politechnica University of Bucharest, 1-7 Polizu Gheorghe Str., 11061, Bucharest, Romania

2National Agency of Medicines and Medical Devices, 48 Av. Sanatescu, 011478, Bucharest, Romania

'Valahia University, Materials Department, 13 Sinaia Aley, 2 King Carol I Blvd., 130024, Targoviste, Romania

${ }^{4}$ National Research and Development Institute for Chemistry and Petrochemistry - ICECHIM, 202 Splaiul Independentei, 060021,

Bucharest, Romania

${ }^{5}$ Multidisciplinary Scientific and Technologic Research Institute, 13 Sinaia Aley, 130004, Targoviste, Romania

Verteporfirin is the active substance of the medicine Visudyne (the basic form porphyrin of the medicine) approved and in use for ophthalmic diseases and tumor types. Because the informations from literature about degraded of this porphyrins are greatly reduced, we propose in this paper to separate the different degraded forms of this porphyrin by using polysulfone membrane polymer type. In this paper are presented some analytical results of verteporfirin before and after passing degraded form of the porphyrins over these membranes.
\end{abstract}

Keywords: verteporphyrin, polysulfone membrane, photodegradation

Porphyrins and their complexes of metals, by their aromatic and non-bonding electrons of the atoms of nitrogen, have become important therapeutic applications as photosensitizers (PS) in the improving and cure of cancerous tumors by the so-called photodynamic therapy of cancer (PDT) [1]. Photodynamic therapy is used in various eye diseases using the following photosensitizers: hematoporphyrin derivative (HPD), dihematoporfirina ether (DHE), phthalocyanine sulfonated aluminum (CLAL-TSPC) or derivative monoacids benzoporphyrin (BPD-MA) $[2,3]$. These photosensitizers have been experienced so far in animal models or human patients with laser radiation or lamp with the wavelength of maximum absorption of the PS, leading to partial or complete necrosis of small tumors [4-8] (table 1).

In recent years clinical nanomedicine has emerged as an alternative in using phototerapeutics nanotechnology and nanomaterials with major impact on disease management.Photonanomedicine (PNM) is a personalnized approach in pathologies like cancer and non-cancer diseases. In this regard, photodynamic therapy (PDT) and advanced imaging nanotechnology will

Table 1

EXAMPLES OF PHOTODYNAMIC THERAPY OF CANCER (PDT) TESTS WITH VARIOUS PHOTOSENSITIZERS (PS)

\begin{tabular}{|c|c|c|c|}
\hline $\begin{array}{l}\text { Nr. } \\
\text { crt. }\end{array}$ & PS & Application type & Bibliography \\
\hline \multirow[t]{5}{*}{1} & $\begin{array}{l}\text { BPD-MA, } 2 \mathrm{mg} / \mathrm{kg} \text { in } \\
\text { low-density lipoprotein } \\
\text { (LDL) }\end{array}$ & $\begin{array}{l}\text { in Greene melanoma treatment of hamster, } \\
\lambda=692 \mathrm{~nm} \text {, dye laser, } \\
\text { Results: thrombosis, after endothelial damage cell membranes }\end{array}$ & [9] \\
\hline & $\mathrm{HPD}$ & $\begin{array}{l}\text { in Irian melanoma treatment and cilar body, } \\
\text { with } \lambda=630 \mathrm{~nm} \text { with low irradiation }(18-200 \mathrm{~mW} / \mathrm{cm} 2) \text { and } \\
\text { fluency large }(1400 \mathrm{~J} / \mathrm{cm} 2 \text { and } 2566 \mathrm{~J} / \mathrm{cm} 2) \\
\text { Results: incomplete necrosis of ciliary body tumors and } \\
\text { refractory severe irritation even with enucleation and iris } \\
\text { melanoma clinical complete response }(1080 \mathrm{~J} / \mathrm{cm} 2)\end{array}$ & [10] \\
\hline & $\begin{array}{c}\mathrm{HPD}, \\
3-5 \mathrm{mg} / \mathrm{kg}\end{array}$ & $\begin{array}{l}\text { in Choroidal melanoma treatment } \\
\text { with } \lambda=630 \mathrm{~nm} \text {, distributed transcornean from a xenon arc } \\
\text { lamp or a dye laser pumped with argon, } \\
\text { Results: tumor necrosis pathological lesions or tumor necrosis } \\
\text { limited }\end{array}$ & [11] \\
\hline & $\begin{array}{c}\mathrm{HPD}, \\
5-7,5 \mathrm{mg} / \mathrm{kg}\end{array}$ & $\begin{array}{l}\text { in Amelanotic melanoma, Choroidal melanoma, } \\
\text { with red light ( } \lambda=620-630 \mathrm{~nm} \text { ), transpupilar transcleral (in } 3 \\
\text { cases) } \\
\text { Results: cutaneous photosensitivity phenomena, chemozis, } \\
\text { reducing irritation and vision }\end{array}$ & [11] \\
\hline & $\begin{array}{c}\mathrm{HPD}, \\
5 \mathrm{mg} / \mathrm{kg}\end{array}$ & $\begin{array}{l}\text { in Retinoblastoma treatment } \\
\text { with } \lambda=630 \mathrm{~nm}, 300 \mathrm{~mW} / \mathrm{cm} 2,270 \mathrm{~J} / \mathrm{cm} 2 \\
\text { Results: angionecroza, thrombus formation and destruction of } \\
\text { tumor cells, tumor tissue to a depth of about } 6 \mathrm{~mm}\end{array}$ & {$[12]$} \\
\hline
\end{tabular}

*email: rodica_ion2000@yahoo.co.uk; Phone: (+40) 213163094 


\begin{tabular}{|l|l|l|c|}
\hline & $\begin{array}{c}\text { verteporfin (BPD-MA), } \\
\mathrm{mg} / \mathrm{m}^{2}\end{array}$ & $\begin{array}{l}\text { in Choroidal hemangioma treatment, } \\
\text { laser diode, } \lambda=692 \mathrm{~nm} \text { and } 100 \mathrm{~J} / \mathrm{cm} 2 \text { irradiation, } \\
\text { Results: the total regression of lesions and improvement of } \\
\text { visual acuity, retinal edema and resorption due to serous } \\
\text { retinal solving takeoff and cystoid macular edema }\end{array}$ & {$[13]$} \\
\hline & $\begin{array}{l}\text { in Macular of degeneration age related treatment, } \\
\text { with }(\lambda=689 \mathrm{~nm}) \\
\text { verteporfin } 6 \mathrm{mg} / \mathrm{m}^{2} \\
\end{array}$ & $\begin{array}{l}\text { Results: } 67 \% \text { of verteporfin-treated eyes lost less than } 15 \\
\text { letters in visual acuity (approximately } 3 \text { lines), compared with } \\
39 \% \text { of patients receiving placebo (p<0.001) }\end{array}$ & \\
\hline
\end{tabular}

contribute to the PNM development of formulations, such as drug Visudyne ${ }^{\circledR}[16]$.

Medicine Visudyne, with verteporfin as active substance, is a benzoporphyrin derivative recognized on pharmaceutical market as a medicinal product (approved), acting photosensitizing agent in photodynamic therapy. Because this medicine is extremely photosensitive, it is necessary to separate photodegradable forms of this medicine, and in this paper we propose to approach a new separation method of photodegradable forms by using composite polymer membranes of polysulfone (PSf) with N-methylpyrrolidone (NMP) and magnetite.

\section{Experimental part}

\section{Materials and methods}

For this experiment I used polysulfone - Polysulfone type resin (PSf), pellets, nominal M. W. 75000; density: $1.24 \mathrm{~g} /$ $\mathrm{cm}^{3}$ 1-methyl-2-pyrrolidone ( $\mathrm{N}$-methylpyrrolidone): $\mathrm{C}_{5} \mathrm{H}_{0} \mathrm{NO}$ - Merck (NMP); content: 99\%; molecular weight: $99.13 \mathrm{~g} / \mathrm{mol}$; density at $20^{\circ} \mathrm{C}: 1.03 \mathrm{~g} / \mathrm{mL}$; solubility in water: $1000 \mathrm{~g} / \mathrm{L}$ at $25^{\circ} \mathrm{C}$; boiling point: $202^{\circ} \mathrm{C}$.

A mixture of $2 \mathrm{~g}$ of magnetite, 20 (or 200) $\mathrm{mL}$ of NMP methyl pyrrolidone $10 \%$ polysulfone dissolved 50 glass beads of $2 \mathrm{~mm}$ diameter to homogenise the composition is placed in a planetary mill of the type Retsch mixture They are left for $7 \mathrm{~h}$ at a speed of $300 \mathrm{rpm}$. Thereafter, a quantity of polymer solution and magnetite, $5 \mathrm{~mL}$, is deposited on a glass substrate spectral and chromatographic with Roel type is extended to a standard thickness of $250 \mu \mathrm{m}$. Polymer film deposited on glass is immersed in the coagulation bath (distilled water and iso-propanol, $50 \%$ ) specially prepared. Membrane formation was carried out for $15 \mathrm{~min}$. The appearance of membranes is show $\mathrm{n}$ in figure 1.

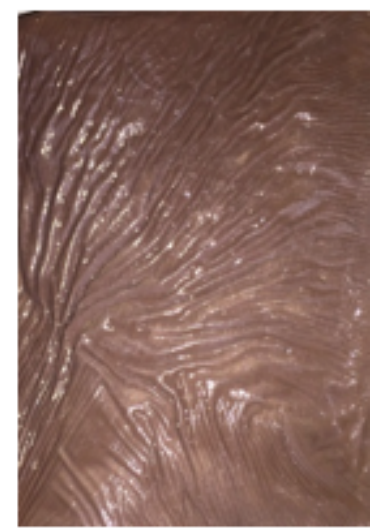

Fig. 1. Composite membrane polysulfone NMP magnetite

Verteporfin (Visudyne, BPD) (Vys) is a derivative benzoporphyrin. The chemical structure is shown in scheme 1 . The molecular formula of this compound is $\mathrm{C}_{4} \mathrm{H}_{42} \mathrm{~N}_{4} \mathrm{O}_{8^{\prime}}$ and the molecular weight is 718.8 .
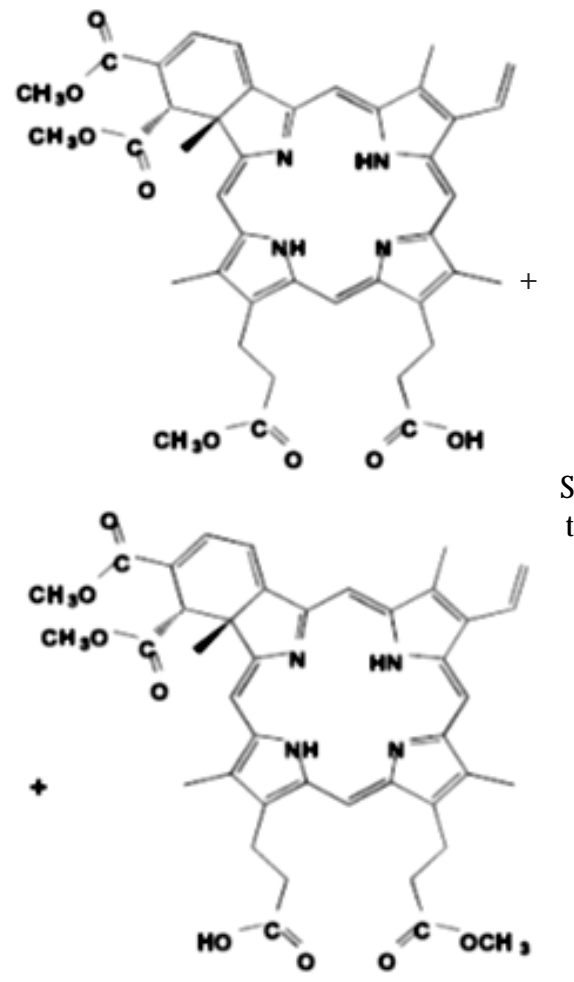

Scheme 1. Structure of the isomeric forms of verteporfin (1: 1)

\section{Apparatus}

Absorption spectra were registered with a SPECORD M 400, Carl Zeiss J ena spectrophotometer with double beam and equipped with a microprocessor. Quartz cuvettes with $0.5-2 \mathrm{~cm}$ optical path lengths and containing $1 \mathrm{~mL}$ of cell suspension each were used. Molar extinction coefficients at a given wavelength, were obtained using the BeerLambert law over the concentration range $10^{-4}-10^{-7} \mathrm{~mol}$. $\mathrm{dm}^{-3}$. The compound was also characterized by Fourier transformed infrared spectroscopy (FT-IR, Perkin-Elmer Spectrum One FT-IR Spectrometer), using the $\mathrm{KBr}$ pellets method.

\section{Results and discussions}

The membrane is known as a phase or structure that is interposed between two stages or compartments may impede / hold / transfer / transport a substance or species of particles. Polysulfone membrane matrix provides an excellent support for various compounds or drugs [17].

Visudyne is indicated for the treatment of adults with age-related macular degeneration (AMD) exudative (wet) with choroidal neovascularisation (CNV) or predominantly classic subfoveal adults with subfoveal choroidal neovascularisation secondary to pathological myopia [18]. Visudyne contains the active substance called verteporfirinã, which is activated by light from a laser treatment called photodynamic therapy [19].

From structurally and chemically point of view, verteporfin (BPDMA) is a part of the second generation of drugs PDT recently approved in North America and Europe 


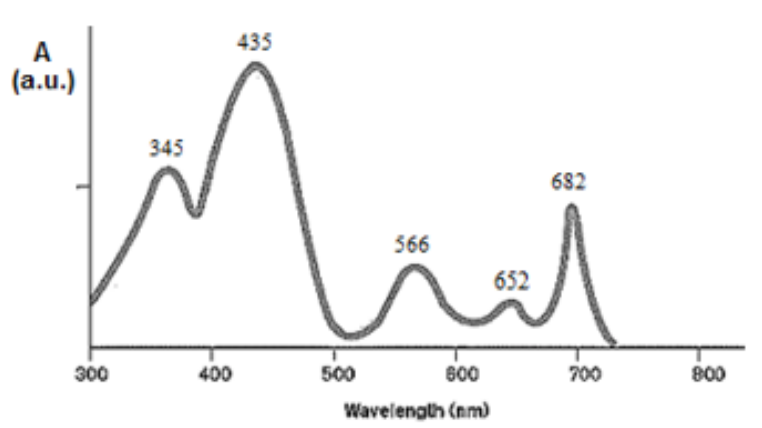

Fig. 2. Figure absorption spectrum Visudyne

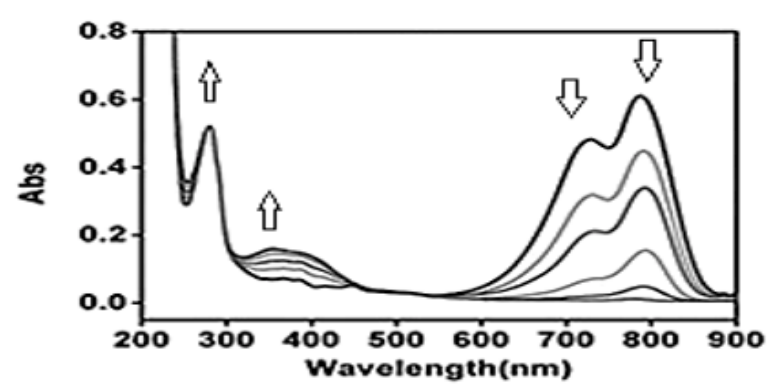

Fig. 3. The change of absorption spectra during photobleaching process (polychromatic light; Dt $\div 0 . . .1300 \mathrm{~s}$ )

Scheme 2 . The main photobleaching products of porphyrins

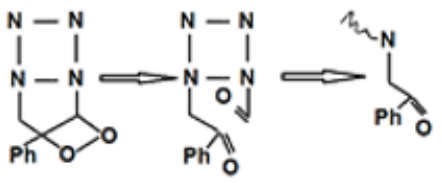<smiles>CNC(=O)CC=CC(=O)N(C)Cc1ccccc1</smiles><smiles>CCCNC(=O)CCC</smiles><smiles>CCCC(=O)N(C)C(O)C(=O)N[C@@H](C)CCC</smiles>

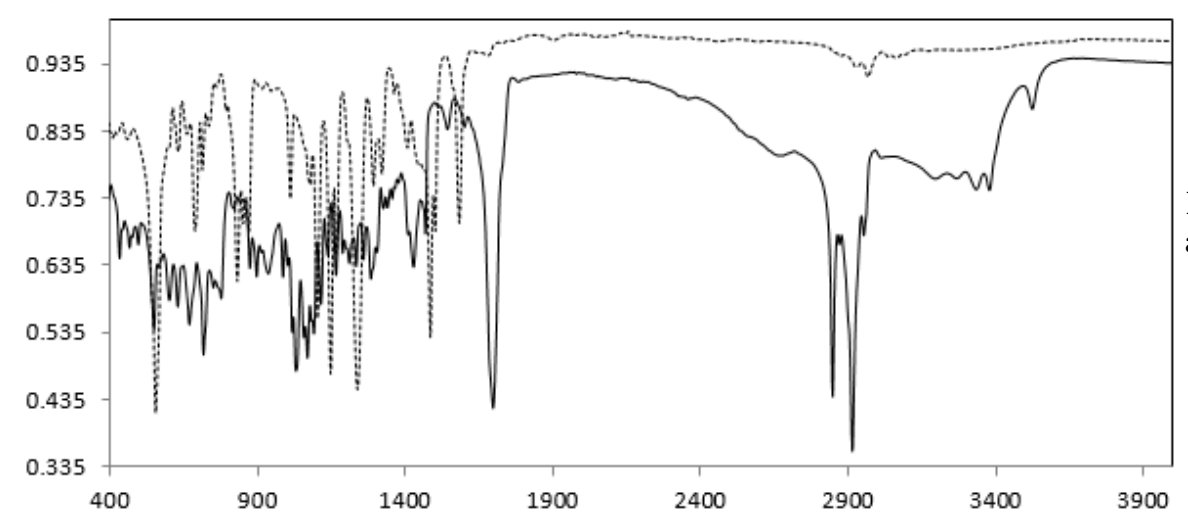

Fig. 4. FTIR spectrum of Vys before (full line) and after (dot line) photodegradation process as the Visudyne ${ }^{\circledR}$ for the treatment of macular degeneration age-related macular degeneration. Since this porphyrin (as otherwise all porphyrins) exhibit a high capacity photolysis, it is necessary to investigate these processes in aqueous solvents.

Verteporfina (Visudyne, BPD) is a benzoporphyrin derivative with absorption at $690 \mathrm{~nm}$, as it is shown in figure 2; this longer wavelength allows deeper penetration due to extended conjugation of the macrocycle. The free carboxylic acid groups and ester groups provide the necessary amphiphilicity, allowing rapid accumulation and expelling from tumors.

Porphyrin photodegradation (photobleaching) involves the formation of photoproducts, with absorption at $320 \mathrm{~nm}$, figure 3, in good agreement with other literature reports [21]. This is visible by a slightly discoloration that occur together with an absorption decrease at $652 \mathrm{~nm}$.

The porphyrin is losing its absorbance at some wavelength and new spectral bands appear this being in agreement with the photo formation of new compounds (scheme 2).

For separating the degraded forms of porphyrins, we used the above-prepared membranes, and the FTIR spectra before and after separation through membranes is visible in figure 4.

Analyzing the FTIR spectra it can be seen the following bands characteristic both for porphyrin and for the above mentioned degradation products.

Vys initial $\left(\mathrm{cm}^{-1}\right)$ : $3320-\mathrm{v}(\mathrm{N}-\mathrm{H})$; $3110-\mathrm{v}(\mathrm{CH})$ metinice; 3030; 2930; $2850-\mathrm{v}(\mathrm{CH} 3 ; \mathrm{CH} 2 ; \mathrm{CH})_{\text {fenil }} ; 1580-\mathrm{v}(\mathrm{C}=\mathrm{N})$;
$1490-\delta(C-H) ; 1160$ - def. cycle; 1075 - def. cycle; 985 $v(\mathrm{CH})_{\text {metinice }} 840$ - def. cycle; $765-\pi$ cycle; $730-\pi$ cycle. Vys fotodegradat $\left(\mathrm{cm}^{-1}\right)$ : 2930; 2850- v(CH3; $\left.\mathrm{CH} 2\right)$; $1600-v(C=0) ; 1490-d(C-H) ; 1160$ - def. cycle; $1075-$ def. cycle; $985-v(\mathrm{CH})_{\text {metipice; }} 975-\mathrm{v}(-0-0-) ; 840$ - def. cycle; 765 - $\pi$ cycle; $530 \pi$ cycle.

Analyzed by optical microscopy, the membranes differ as porosity and integrity by passing and separating the photodegradation products from Vys (fig. 5). The pores become larger and not-uniform distributed. Practically, the membrane looks like a sieve with high number of pores and very fragile, easy to be broken.

\section{Conclusions}

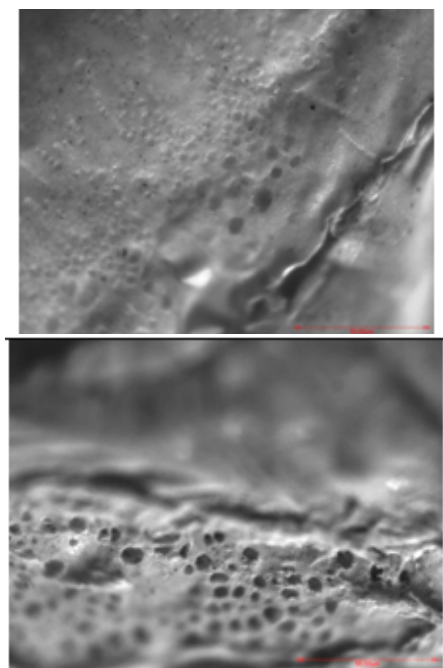

Fig. 5. The optical microscopy of the membrane before (top) and after (down) photodegradation process 
Visudyne this medicine with verteporfin as active substance is a derivative benzoporphyrin predisposed to aggregation and photodegradation. Therefore, for the separation of its forms, in this paper we tested a new method of separating through some polymeric membranes composite polysulfone membrane-N-methyl pyrrolidone (PSf-NMP). The obtained results provided by various spectral techniques (UV-Vis absorption spectrophotometry, FTIR and microscopy) of all of these forms of Visudyne and separating ionized forms degraded by crossing polysulfone membrane type with NMP and magnetite.

\section{References}

1.ION R.M., Porphyrins for tumor destruction in photodynamic therapy, Current Topics in Biophysics, 24, no. 3, 2000, p. 32

2.MILLER, J.W., STINSON, W.G., GREGORY, W.A., Phthalocyanine photodynamic therapy of experimental iris neovascularization, Ophthalmology, 98, 1991, p. 1711

3.PACKER, A.J., TSE, D..T, GU, X-Q, Hematoporphyrin photoradiation therapy for iris neovascularization, Arch. Ophthalmol., 102, 1984, p. 1193

4.GOMER, C.J., JESTER, J.V., RAZUM, N.J ., Photodynamic therapy of intraocular tumors examination of hematoporphyrin derivative distribution and long-term damage in rabbit ocular tissue, Cancer Research, 45, 1985, p. 3718

5.HENDERSON, B.W., FARRELL, G., Visible implications of vascular damage for tumor cell inactivation in vivo: comparison of different photosensitizers, SPIE, 1065, 1989, p. 1

6.PASCU, M.L., DANAILA, L., VOICU, L., STAICU, A., TRUICA, S., ION, R.M., Spectroscopic characteristics of mep used in PDT, Oftalmologia, 58, no. 2, 2003, p. 73

7.IONITA, M.A., ION, R.M., CARSTOCEA, B., GAFENCU, O.L., NICULESCU, V.I., Photodynamic occlusion of ocular neovascularization with $B 2$ vitamin, Oftalmologia, 54, no. 3, 2002, p. 82 8.IONITA, M.A., ION, R.M., CARSTOCEA, B., Photochemical and photodynamic properties of vitamin B2 (Riboflavin) and liposomes, Oftalmologia, 58, no. 3, 2003, p. 29

9.HAIMOVICl, R., KRAMER, M., FLOTTE, T.J., Localization of benzoporphyrin derivative in the rabbit eye, Invest. Ophthalmol. Vis. Sci., 34, 1993, p. 103
10.TSE, D.T., DUTTON, J., JEINGEIST, T.A., Hematoporphyrin photoradiation therapy for intraocular and orbital malignant melanoma, Arch. Ophthalmol., 102, p. 833

11.WINTHER, J., Porphyrin photodynamic therapy in an experimental retinoblastoma model, Ophthalmic. Paed. Genet., 8, 1987, p. 49 12.HENDERSON, B.W., BUSCH, T.M., VAUGHAN, L.A., FRAWLEY, N.P., BABICH, D., SOSA, T.A., ZOLLO, J.D., DEE, A.S., COOPER, M.T., BELLNIER, D.A., GRECO, W.R., OSEROFF, AR, Photofrin photodynamic therapy can significantly deplete or preserve oxygenation in human basal cell carcinomas during treatment, depending on fluence rate, Cancer Research, 60, no. 1, 2000, p. 525

13.SICKENBERG, M., Early detection, diagnosis and management of choroidal neovascularization in age-related macular degeneration: the role of ophthalmologists, Ophthalmologica, 215, 2001, p. 247

14.MILLER, J.W., SCHMIDT-ERFURTH, U., SICKENBERG, M., POURNARAS, C., LAQUA, H., BARBAZETTO, I., ZOGRAFOS, L., Photodynamic therapy of subfoveal choroidal neovascularization in age-related macular degeneration with verteporfin, Arch. Ophthalmol., 117, 1999, p. 1329

15.FREUND, K.B., YANNUZZI, L.A., SORENSON, J.A., Age-related macular degeneration and choroidal neovascularization, Am. J. Ophthalmol., 115, 1993, p. 786

16.OBAID, G., BROEKGAARDEN, M., BULIN, A.-L., HUANG, H.-C., KURIAKOSE, J., LIU, J ., HASAN, T., Photonanomedicine: a convergence of photodynamic therapy and nanotechnology, Nanoscale, 8, 2016, p. 12471

17.SIMIONESCU, S., TEODORESCU, S., ION, R.M., NECHIFOR, G., Polymer membranes for selective separation of ionizing forms of TPPs4 as drug in photodynamic therapy, Mat. Plast., 53, no.2, 2016, p. 194

18.NECHIFOR, G., POPESCU, G., Asymmetric membranes prepared by immersion-precipitation technique, Rev. Roum. Chim., 35, no. 79, 1990, p. 899

19.ORMOND, A., FREEMAN, H., Dye sensitizers for photodynamic therapy, Materials, 6, 2013, p. 817

20.HOULE, J., BAIN, S., AZAB, M., Strong a - clinical pharmacokinetics of verteporfin in healthy volunteers and patients with CNV, Invest. Ophthalmol. Vis. Sci., 42, 2001, p. 437

21.ION, R.M., MANDRAVEL, C., The photodegradation reaction of some porphyrins, southern, Braz.J.Chem.Soc., 5, 1996-1997, p. 111

Manuscript received: 14.11 .2016 